\title{
Mary Bateson
}

THE name of Mary Bateson has been so familiar in the last 1 seventeen volumes of this Review, and her work has added so notably to its reputation, that her sudden and untimely death has come to our contributors-even to those who were not acquainted with her-with the shock of a personal loss. Among the many letters which I have received day by day since 30 November hardly any has failed to give expression to this ; and I am sure that I am faithfully representing the opinion of our contributors when I say that since the death of our first two editors and of Lord Acton no loss has been more widely or deeply felt by them. It is right that in these pages I should begin by saying this; for although Miss Bateson's work for us formed but a small part of her total production it was the Review, under the stimulus of Bishop Creighton, that started her on the lines of study which she afterwards pursued on a larger scale and with remarkable results.

The daughter of the late master of St. John's College, Cambridge, she was brought up in a household busy with the thoughts and plans of vigorous liberalism, and to these she remained devoted, with increasing intensity, as long as she lived. But her I must only refer in passing to the zeal with which she threw herself into public work, in particular for the promotion of anything that concerned the welfare of women. She entered Newnham College in 1884, just before Creighton went to Cambridge as professor of ecclesiastical history. He very soon discovered of what metal she was made, and to him she owed the influence which decided her career. As soon as she had taken her first class in the historical tripos his counsels led her to prepare herself for strict historical study. She was not to be the populariser of other people's workan ambition which satisfies most of the historical teachers in our universities - but to do the work herself. She was to begin by a hard, dogged apprenticeship, transcribing her own materials. In this way she plunged into the records of the sixteenth century, and copied out the documents relative to the Pilgrimage of Grace which were printed in two numbers of our fifth volume. But this was only apprenticeship. Creighton's aim was to attach her to the middle ages, and to induce her to write a bistory of monasticism. 
For this she made considerable collections, among which should be mentioned her papers on Rules for MIonks and Secular Canons and A Worcester Cathedral Book of Ecclesiastical Collections in our ninth and tenth volumes, and the Origin and Early History of Double Monasteries, which appeared in the Transactions of the Royal Historical Society for 1899 (New Series, vol. xiii.), though mainly written some years earlier. But the book, so far as is known, never went further. Miss Bateson had in the meantime been attracted by economic history, and from that was led on to the study in which she attained pre-eminent distinction. On this subject I am permitted by the kindness of Professor James Tait to quote a statement which he has written at my request.

'As early as 1891 Miss Bateson collaborated with Professor' Maitland in an edition of the borough charters of Cambridge, and some time later she undertook the far heavier task of calendaring the municipal records of Leicester. But until 1899, the year of the publication of the first volume of the calendar, there is no sign in her contributions to this Review that she was being diverted from ecclesiastical history to the studies in municipal origins which were to form the work of her life. Her long review of Meitzen's Siedelung und Agrarwesen der Germanen two years earlier showed indeed that she had become greatly interested in some cognate problems raised in Professor Maitland's Domesduy Book and Beyond, published in that year. The review was professedly explanatory and appreciative rather than critical, but was marked by a thorough grasp of the questions involved and unobtrusively indicated the weak links in Meitzen's argument.

- The three volumes of the Records of Leicester which appeared in 1899, 1901, and 1905 at once took rank among the two or three really adequately edited collections of English municipal documents. The qualities that most attract attention are her power of rapid yet careful work and her clear appreciation of what is significant in almost bewildering masses of detail. Her introductions are models of lucid and orderly statement and throw much new light upon some controverted questions of the constitutional history of our English boroughs, as, for instance, upon the relations of the gild merchant to the ancient town authorities, where she modifies some of Dr. Gross's conclusions, and upon the real nature of the "oligarchical" changes of the fifteenth century.

- While she was still engaged upon the earlier stages of this historical analysis a casual suggestion of Professor Maitland's that the "Lex Bretonica" of the Preston custumal might conceal a reference to those customs of Breteuil which, Domesday records, were enjoyed by the burgesses of Rhuddlan in 1086 dropped a seed which germinated in the brilliant piece of historical synthesis which appeared in this Review in 1900-2 under the title of The

voL. XXII.—No. LXXXY. 
Lans of Bretenil. The idea that the "Britolium" which was the fruitful mother of the customs of so many boroughs in the west of England, Wales, and Ireland was not, as had always been supposed, Bristol, but the little Norman bourg of Breteuil, was indeed a fortunate inspiration, but the chief merit of the articles lies in the extraordinary industry and acuteness with which this clue was followed ont. All Miss Bateson's subsequent work was coloured by the investigations which she made in working out the ramifications of this foreign influence. The wide acquaintance with English municipal custom, with connected or parallel foreign usage, and with the great continental literature of town origins which she thereby gained immensely widened her outlook upon the problems of urban growth. The isolation of borough law, its double character as archaic survival stereotyped by charters and custumals, and, in a minor degree, as anticipation of statute law, were strongly impressed upon her. Working on these lines, and constantly extending her knowledge of the vast unprinted material of the subject, she produced for the Selden Society what is without doubt her most elaborate and mature work, the Borough Customs, of which the first volume appeared in 1904 and the second only a few months before her death. Such a sciertifically arranged digest of a vast body of unclassified "custom " would in itself constitute a permanent claim to the gratitude of legal and historical students, but its value is doubled by the introductions, in which her unequalled knowledge of the comparative antiquities of the subject is brought to bear upon the elucidation of the obscurest problems of archaic law. In width of learning and grasp of legal subtleties it need not fear comparison with the best work of our most famous legal historians. The tale of Miss Bateson's contributions to municipal history would not be complete without a reference to the elaborate study in this Review of $A$ London Municipal Collection of the Reign of.Joln (1902), to the careful edition of the Cambridge Gild Records (1903), and the more recent discussion in this Review of the disputed interpretation of the passages in Domesday Book which connect burgesses of certain boroughs with rural manors. To her acquaintance with the later composition of the burgess body in towns like Leicester we owe the fruitful suggestion that some at least of these burgesses may have been what were afterwards known as foreign or out-burgesses, who enjoyed burghal privileges, though they did not reside in the town.'

On the Borough Customs I may add a few sentences from Professor Maitland.' 'I was astonished,' he says, ' at the diligence

1 While these sheets are passing throngh the press I leam the grievous news that Dr. Aritland also is lost to us. Of whit this loss means, something will be satil in our 
and zest with which Miss Bateson collected her materials (often hunting in quarters that few would have thought of), at the enormous amount of old law that she was content to read and master, at her vigorous grasp of big historical questions, at the sanity and sobriety of her judgment in note and comment, at her cheerful willingness to begin again if things were not to her liking, and above all perhaps at her energetic determination to make her book as true as it could be made within certain narrowly assigned limits of space and time. I do not know the man who both could and would have done so much and so well. She worked unselfishly for little pay and for little glory; but her work will live, and for a long time to come any one who writes about the history of our towns, or, indeed, about the growth of English law, will be bound to keep her book close at hand.' ${ }^{1}$

Work of such compass and fibre might seem more than enough for a short life of forty-one years. But Miss Bateson's energy was inexhaustible. At one time she turned to the Newcastle papers in the British Museum, and edited A Narrative of the Changes in the Ministry, 1765-1767, for the Camden Series of the Royal Historical Society (1898), besides writing, some years earlier, a delicious article os Clerical Preferment under the Duke of Newcastle in our seventh volume. At another she was persuaded by Lord Acton to write a chapter on The French in Canada for the Cambridge Modern History, vol. vii. (1903). A favourite study of hers was the history of medieval libraries, on which she spent much hard work. Her Catalogue of the Library of Syon Monastery, Isleworth, was published in 1898 , and it was the fact of her occupation on this catalogue that led me to ask her to help me in the edition of John Bale's Index Britanniae Scriptorum, which we finished in 1902. How valuable her collaboration was, especially in the exploring of manuscripts at Cambridge and in the identification of early printed books, I have thankfully indicated in the preface. Miss Bateson also edited George Ashby's Pocms for the Early English Text Society in 1899, and two volumes of records of the University of Cambridge for the years 1488-1544 (Grace Book B) for the Cambridge Antiquarian Society in 1903 and 1905. Lastly, in 1903 she wrote a volume on Medieral England, 1066-1350, which contains a brilliantly original sketch of English society and ranks quite by itself in the series of The Story of the Nations.

In early days Creighton used to be doubtful of Miss Bateson's power to acquire a good historical style, and it is true that she seldom made enough allowance for the limitations of her reader's

next number. Here I may mention that it was he whom I first begged to write the notice of Miss Bateson for this Review, but there was a reason which to his scrupulous mind made it inadvisable that he should do this; he had already witten one for the Athenceun (8 December 1906).

1 Quoted in the Canbridge Revicw, 6 December 1906, p. 136. 
intelligence. She rushed through her sentences, and did not always take heed whether they would mean all she intended to those who were not so full of the subject as she was. There were the two dangers of assuming too much knowledge in the reader and of alluding, as though to familiar things, to facts with which perhaps only a very few people were properly acquainted. Some felt that she made a technical matter unnecessarily technical. It was also true that in her eagerness to complete any work she was at she did not always give herself time to add the finishing touches. But when she applied herself to a plain narrative she could be as direct and as telling as possible. Of this an excellent example may be found in her chapter on The French in Canada in the Cambridge Modern History, which I mention here only as a specimen of style, for I am not competent to express an opinion on the matter of a piece of work lying quite outside my own line of study.

Mrs. Creighton has been so good as to put together some notes about Miss Bateson, from which the following sentences may serve in some measure to show the impression which she made on old and tried friends:- The strong, straight purpose of her life is what strikes one on looking back at it. It was a genuine singleminded devotion to knowledge. She was absolutely humble about her own powers; no one would have gathered from talk with her that she was one of the best, if not the best, women historical students that England has ever produced. She did not care for her own fame; her one desire was to do good work. Her industry was unfailing. I remember my husband coming back from a brief visit to Cambridge once and saying, "It is splendid how Mary Bateson works. Some one said to me, "It is an example to every one to see her at work in the library." ". . . It was a fine life, simple, strong, given to the pursuit of knowledge. Her big, generous nature was always ready to admire the work of others. There was never anything small or mean about her. As a friend she was absolutely loyal and faithful. She never changed.' This is truly said. She was a real friend. No differences in matters of opinion stood in the way. Her kindness and her joyous spirit, no less than her vigorous intellect, will remain a gracious memory with those who knew her.

Reginald L. Poole. 